\title{
The impact of plasma epstein-barr virus DNA and fibrinogen on nasopharyngeal carcinoma prognosis: an observational study
}

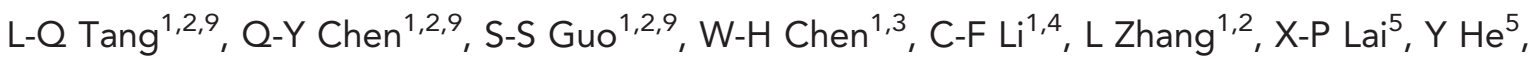

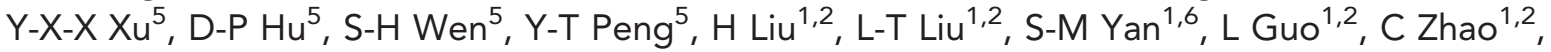

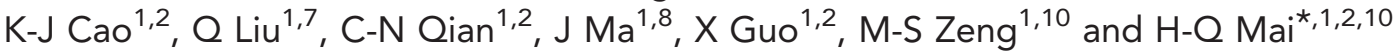

${ }^{1}$ Sun Yat-sen University CancerCenter, State Key Laboratory of Oncology in South China, Collaborative Innovation Center for Cancer Medicine, 651 Dongfeng Road East, Guangzhou 510060, China; ${ }^{2}$ Department of Nasopharyngeal Carcinoma, 651 Dongfeng Road East, Guangzhou 510060, China; ${ }^{3}$ Department of Clinical Laboratory, 651 Dongfeng Road East, Guangzhou 510060, China; ${ }^{4}$ Department of Information Technology, 651 Dongfeng Road East, Guangzhou 510060, China; ${ }^{5}$ ZhongShan School of Medicine, Sun Yat-sen University, 651 Dongfeng Road East, Guangzhou 510060, China; ${ }^{6}$ Department of Pathology, 651 Dongfeng Road East, Guangzhou 510060, China; ${ }^{7}$ Department of Statistics and Epidemiology, 651 Dongfeng Road East, Guangzhou 510060, China and ${ }^{8}$ Department of Radiation Oncology, 651 Dongfeng Road East, Guangzhou 510060, China

Background: The impact of combining plasma fibrinogen levels with Epstein-Barr Virus DNA (EBV DNA) levels on the prognosis for patients with nasopharyngeal carcinoma (NPC) was evaluated.

Methods: In this observational study, 2563 patients with non-metastatic NPC were evaluated for the effects of circulating plasma fibrinogen and EBV DNA levels on disease-free survival (DFS), distant metastasis-free survival (DMFS), and overall survival (OS).

Results: Compared with the bottom biomarker tertiles, TNM stage-adjusted hazard ratios (HR, 95\% confidence intervals (Cls)) for predicting DFS in fibrinogen tertiles 2 to 3 were 1.26 (1.00 to 1.60) and 1.81 (1.45 to 2.26), respectively; HR for EBV DNA tertiles 2 to 3 were 1.49 (1.12 to 1.98$)$ and 4.24 (3.27 to 5.49), respectively. After additional adjustment for established risk factors, both biomarkers were still associated ( $P$ for trend $<0.001$ ) with reduced DFS (HR: 1.79, 95\% Cl, 1.43 to 2.25 for top fibrinogen tertiles; HR: $4.04,95 \% \mathrm{Cl}: 3.10$ to 5.27 for top EBV DNA tertiles compared with the bottom tertiles). For patients with advanced-stage disease, those with high fibrinogen levels $\left(\geqslant 3.34 \mathrm{gl}^{-1}\right)$ presented with worse DFS, regardless of EBV DNA $\geqslant 4000$ or $<4000$ copies $\mathrm{ml}^{-1}$ subgroup. Similar findings were observed for DMFS and OS.

Conclusions: Circulating fibrinogen and EBV DNA significantly correlate with NPC patients survival. Combined fibrinogen and EBV DNA data lead to improved prognostic prediction in advanced-stage disease.

Nasopharyngeal carcinoma (NPC) is endemic in Southern China and Southeast Asia, where a peak incidence of 50 cases per 100000 has been reported (Wee et al, 2010). Radiotherapy is the primary treatment modality, and concurrent chemoradiotherapy with or without adjuvant chemotherapy is the primary regimen for patients with locoregionally advanced NPC. However, patients with similar stages and histologic classifications have markedly different survival outcomes given the heterogeneity of protein expression profiles (Ludwig and Weinstein, 2005; Wei and Sham, 2005). Various studies have attempted to identify molecular

\footnotetext{
*Correspondence: Professor H-Q Mai; E-mail: maihq@mail.sysu.edu.cn

${ }^{9}$ These authors contributed equally to this article.

${ }^{10}$ The senior authors contributed equally to this work.
}

Received 3 April 2014; revised 4 June 2014; accepted 18 June 2014; published online 22 July 2014 
biomarkers to predict NPC progression, and numerous promising biomarkers have been evaluated as potential prognosis predictors of NPC. Recently, pretreatment plasma Epstein-Barr Virus (EBV) DNA levels were clinically employed as a useful tool for NPC diagnosis, risk stratification, monitoring and prognosis (Lo et al, 1999; Chan et al, 2002; Leung et al, 2003a; Lin et al, 2004; Leung et al, 2006). EBV DNA levels are considered the most attractive potential biomarker that complements TNM classification in NPC (Ng et al, 2014). Given the biological heterogeneity of cancer, the present staging system, even in combination with plasma EBV DNA levels, remains inadequate for predicting NPC patient prognosis. Therefore, we hypothesise that additional biomarkers could complement EBV DNA levels. These biomarkers could be used in combination to improve the prognostic stratification of NPC patients.

Fibrinogen, a circulating glycoprotein that is a nonspecific acute-phase reactant and important clotting factor, might serve as a useful biomarker in this context. Fibrinogen converts to insoluble fibrin via thrombin, thereby significantly affecting inflammatory response, fibrinolysis, blood clotting, wound healing and neoplasia (Mosesson, 2005). Increased fibrinogen levels influence cancer cell growth, progression and metastasis. Hyperfibrinogenaemias are associated with various human malignancies, including oesophageal (Takeuchi et al, 2007), colorectal (Yamashita et al, 2009), ovarian (Polterauer et al, 2009a), cervical (Polterauer et al, 2009b), and pancreatic cancer (Guo et al, 2009). Nasopharyngeal carcinoma is associated with EBV infection and hence chronic inflammation. Nevertheless, little information is known regarding the clinical significance of fibrinogen and the potential complementary role of fibrinogen and EBV DNA levels in predicting NPC carcinogenesis and progression. Therefore, this large cohort study compared the efficacy of EBV DNA and fibrinogen alone and in combination for predicting NPC patient survival. In addition, this study provides information regarding personalised therapy.

\section{MATERIALS AND METHODS}

Two thousand seven hundred and sixty-seven patients with primary NPC were consecutively recruited from January 2007 to December 2011 at the Sun Yat-sen University Cancer Center, Guangzhou, China. Patients were excluded from this study if they met the following criteria: (1) previously received any anticancer therapy $(n=24)$; $(2)<18$ years old $(n=12)$; (3) pregnant or lactating $(n=8)$; (4) unsuitable for chemotherapy as a result of a liver, kidney, lung or heart deficiency $(n=15)$; (5) a history of previous or synchronous malignant tumours $(n=17)$; (6) have primary NPC metastasis $(n=90)$; or (7) lost during follow-up $(n=38)$. In total, 2563 patients with non-metastatic primary NPC were eligible for analysis.

The routine staging work-up included clinical examination of the head and neck region, magnetic resonance imaging scan from the suprasellar cistern to the collarbone, fibreoptic nasopharyngoscopy, chest radiography, abdominal sonography and whole-body bone scan or whole-body FDG PET/CT. All patients were restaged according to the seventh American Joint Committee on Cancer (AJCC) TNM staging manual. In total, 1126 (43.9\%) patients were treated with conventional two-dimensional (2D) or three-dimensional (3D) conformal radiotherapy radiotherapy, and 1437 (56.1\%) patients were treated with intensity-modulated radiotherapy. In addition, 2183 (87.5\%) patients with stage II-IV disease received platinum-based chemotherapy. Concurrent chemoradiotherapy with or without neoadjuvant or adjuvant chemotherapy was administered for advanced-stage disease (stages III and IV). A stratified multitherapeutic protocol was used. Radiation alone was administered for stage I disease, and radiation alone or with concurrent platinum-based chemotherapy was administered for stage II disease (Chen et al, 2011). Concurrent chemoradiotherapy with or without neoadjuvant or adjuvant chemotherapy was administered for advanced-stage disease (stages III and IV). Neoadjuvant or adjuvant chemotherapy consisting of cisplatin plus 5-fluorouracil or cisplatin plus taxane was administered every 3 weeks for two or three cycles (Chen et al, 2012). Concurrent cisplatin chemotherapy was administered on weeks 1, 4 and 7 of RT. All patients were treated according to the principles of treatment for NPC patients at the Sun Yat-sen University Cancer Center, Guangzhou, China.

Collection of data. Before treatment, baseline clinical data were collected regarding sex, age, hereditary NPC, smoking status and PS as assessed by the Eastern Cooperative Oncology Group (ECOG). Information regarding relevant concurrent diseases, such as cardiovascular disease, diabetes and chronic hepatitis, was collected as previous studies have indicated that these factors promote increased plasma fibrinogen levels (Mora et al, 2006; Sinning et al, 2006; Calvaruso et al, 2008; Lowe et al, 2013; Sapkota et al, 2013). These comorbidities and smoking status were defined as follows: chronic hepatitis B: HBsAg-positive $>6$ months and serum HBV-DNA $\geqslant 2000 \mathrm{IU} \mathrm{ml}^{-1}\left(10^{4}\right.$ copies $\left.\mathrm{ml}^{-1}\right)$ with or without increased alanine transaminase/aspartate transaminase levels; diabetes: fasting plasma glucose level $7.0 \mathrm{mmoll}^{-1}$ and/or $2 \mathrm{~h}$ plasma glucose level $11.1 \mathrm{mmol}^{-1}$ after a $75 \mathrm{~g}$ glucose load or a previous diagnosis of diabetes by a healthcare professional; cardiovascular disease: coronary heart disease, cerebrovascular disease, peripheral arterial disease, rheumatic heart disease, congenital heart disease, deep vein thrombosis, pulmonary embolism, hypertension (systolic blood pressure $140 \mathrm{~mm} \mathrm{Hg}$, diastolic blood pressure $90 \mathrm{~mm} \mathrm{Hg}$ ) or a previous diagnosis of any of these diseases made by a healthcare professional; smoking: patients were identified as current, former or never smokers. Patients who smoked or reported smoking cessation within 1 year at the time of the diagnosis were considered current smokers. Patients who had smoked less than 100 cigarettes during their lifetime were considered never smokers.

Plasma fibrinogen evaluation. A $3 \mathrm{ml}$ fasting blood sample was collected from each patient before treatment and processed within $3 \mathrm{~h}$ of collection. The plasma was stored at $-80^{\circ} \mathrm{C}$ until use in assays. Fibrinogen values were measured by the Clauss method using an Automatic Analyser Sysmex CA7000 (Sysmex Corporation, Kobe, Japan) and reagents according to the SIEMENS AG guidelines (Munich, Germany) (Clauss, 1957; Cook and Ubben, 1990). The results were obtained using a standard curve prepared according to the manufacturer's instructions, and the interassay imprecision (coefficient of variation) was $<10 \%$. Plasma D-dimer concentrations $<3.5 \mathrm{gl}^{-1}$ were considered normal based on the manufacturer's instructions.

EBV DNA, VCA-IgA and EA-IgA measurement. As previously described (Lo et al, 1999; Shao et al, 2004; An et al, 2011), patient plasma EBV DNA concentrations were routinely measured by q-PCR before treatment. EBV-specific VCA/IgA antibodies and $\mathrm{EBV}$-specific EA/IgA antibodies were assessed using a previously described immunoenzymatic assay (Liu et al, 2012b).

Clinical outcome assessment and patient follow-up. Our primary endpoint was disease-free survival (DFS), and our secondary endpoints were distant metastasis-free survival (DMFS) and overall survival (OS). Disease-free survival was calculated from the date of the first NPC diagnosis to the date of the first relapse at any site, death from any cause or the date of the last follow-up visit. DMFS was determined from the date of the first NPC diagnosis to the date of distant relapse or patient censoring at the date of the last follow-up. Overall survival was calculated from the date of the first NPC diagnosis to the date of death from any cause or patient 
Table 1. Patient demographics and clinical characteristics

Number of patients (fibrinogen and EBV DNA tertiles, $n=2563$ )

\begin{tabular}{|l|c|c|c|c|c|c|c|}
\hline & \multicolumn{3}{|c|}{ Fibrinogen, gl } & \multicolumn{4}{c|}{ EBV DNA, copies ml $^{-\mathbf{1}}$} \\
\hline Characteristic & $<\mathbf{2 . 6 7}$ & $\mathbf{2 . 6 7 - 3 . 3 4}$ & $\geqslant \mathbf{3 . 3 4}$ & $<\mathbf{3 2 6}$ & $\mathbf{3 2 6 - 1 1 3 3 3}$ & $\geqslant \mathbf{1 1 3 3 3}$ \\
\hline Age, years & 44 & 47 & 48 & 46 & 46 & 47 \\
\hline Median & 44.82 & 47.61 & 48.33 & 46.27 & 47.15 & 47.31 \\
Mean &
\end{tabular}

Sex

Male

Female

\begin{tabular}{l|l}
635 & 607
\end{tabular}

$607 \quad 645$

\begin{tabular}{l|l}
645 & 608
\end{tabular}

635

220

\section{Histology, WHO type}

\begin{tabular}{|l|c|c|c|c|c|c|}
\hline III II & 820 & 830 & 812 & 810 & 824 & 39 \\
I & 39 & 28 & 26 & 30 & 24 \\
\hline
\end{tabular}

\section{ECOG}

0-1

2

\begin{tabular}{c|c}
856 & 861 \\
5 & 2
\end{tabular}

837

Clinical stage

I

\begin{tabular}{c|c}
\hline 40 & 23 \\
158 & 100 \\
474 & 482 \\
189 & 258
\end{tabular}

\begin{tabular}{c|c}
\hline 6 & 59 \\
46 & 210 \\
446 & 439 \\
341 & 146
\end{tabular}

\begin{tabular}{c|c}
\hline 8 & 2 \\
61 & 33 \\
542 & 421 \\
244 & 398
\end{tabular}

Tumour stage

\begin{tabular}{|c|c|c|c|c|c|c|}
\hline $\mathrm{T} 1$ & 103 & 62 & 27 & 111 & 50 & 31 \\
\hline T2 & 237 & 164 & 113 & 221 & 150 & 143 \\
\hline T3 & 390 & 435 & 420 & 398 & 448 & 399 \\
\hline T4 & 131 & 202 & 279 & 124 & 207 & 281 \\
\hline
\end{tabular}

Node stage

\begin{tabular}{|c|c|c|c|c|c|c|}
\hline $\begin{array}{l}\text { N0 } \\
\text { N1 } \\
\text { N2 } \\
\text { N3 }\end{array}$ & $\begin{array}{c}167 \\
333 \\
298 \\
63\end{array}$ & $\begin{array}{c}167 \\
310 \\
309 \\
77\end{array}$ & $\begin{array}{l}105 \\
257 \\
370 \\
107\end{array}$ & $\begin{array}{c}292 \\
367 \\
168 \\
27\end{array}$ & $\begin{array}{c}97 \\
322 \\
384 \\
57\end{array}$ & $\begin{array}{c}50 \\
211 \\
425 \\
168\end{array}$ \\
\hline \multicolumn{7}{|l|}{ Treatment } \\
\hline $\begin{array}{l}\text { Radiotherapy } \\
\text { Chemotherapy and radiotherapy }\end{array}$ & $\begin{array}{l}168 \\
693\end{array}$ & $\begin{array}{l}125 \\
738\end{array}$ & $\begin{array}{c}80 \\
759\end{array}$ & $\begin{array}{l}229 \\
625\end{array}$ & $\begin{array}{c}83 \\
772\end{array}$ & $\begin{array}{c}61 \\
793\end{array}$ \\
\hline \multicolumn{7}{|l|}{ Radiotherapy technique } \\
\hline $\begin{array}{l}\text { 2DRT/3DCRT } \\
\text { IMRT }\end{array}$ & $\begin{array}{l}414 \\
447\end{array}$ & $\begin{array}{l}355 \\
508\end{array}$ & $\begin{array}{l}357 \\
482\end{array}$ & $\begin{array}{l}355 \\
499\end{array}$ & $\begin{array}{l}367 \\
488\end{array}$ & $\begin{array}{l}404 \\
450\end{array}$ \\
\hline \multicolumn{7}{|l|}{ VCA-IgA } \\
\hline $\begin{array}{l}<1: 80 \\
\geqslant 1: 80\end{array}$ & $\begin{array}{l}246 \\
615\end{array}$ & $\begin{array}{l}249 \\
614\end{array}$ & $\begin{array}{l}231 \\
608\end{array}$ & $\begin{array}{l}321 \\
533\end{array}$ & $\begin{array}{l}223 \\
632\end{array}$ & $\begin{array}{l}182 \\
672 \\
\end{array}$ \\
\hline \multicolumn{7}{|l|}{ EA-IgA } \\
\hline $\begin{array}{l}<1: 10 \\
\geqslant 1: 10\end{array}$ & $\begin{array}{l}391 \\
470\end{array}$ & $\begin{array}{l}375 \\
488\end{array}$ & $\begin{array}{l}343 \\
496\end{array}$ & $\begin{array}{l}465 \\
389\end{array}$ & $\begin{array}{l}356 \\
499\end{array}$ & $\begin{array}{l}288 \\
566\end{array}$ \\
\hline \multicolumn{7}{|l|}{$\mathrm{LDH}, \mathrm{UI}^{-1}$} \\
\hline $\begin{array}{l}<170 \\
\geqslant 170\end{array}$ & $\begin{array}{l}489 \\
372\end{array}$ & $\begin{array}{l}428 \\
435\end{array}$ & $\begin{array}{l}340 \\
499\end{array}$ & $\begin{array}{l}494 \\
360\end{array}$ & $\begin{array}{l}439 \\
416\end{array}$ & $\begin{array}{l}324 \\
530\end{array}$ \\
\hline
\end{tabular}


Table 1. (Continued)

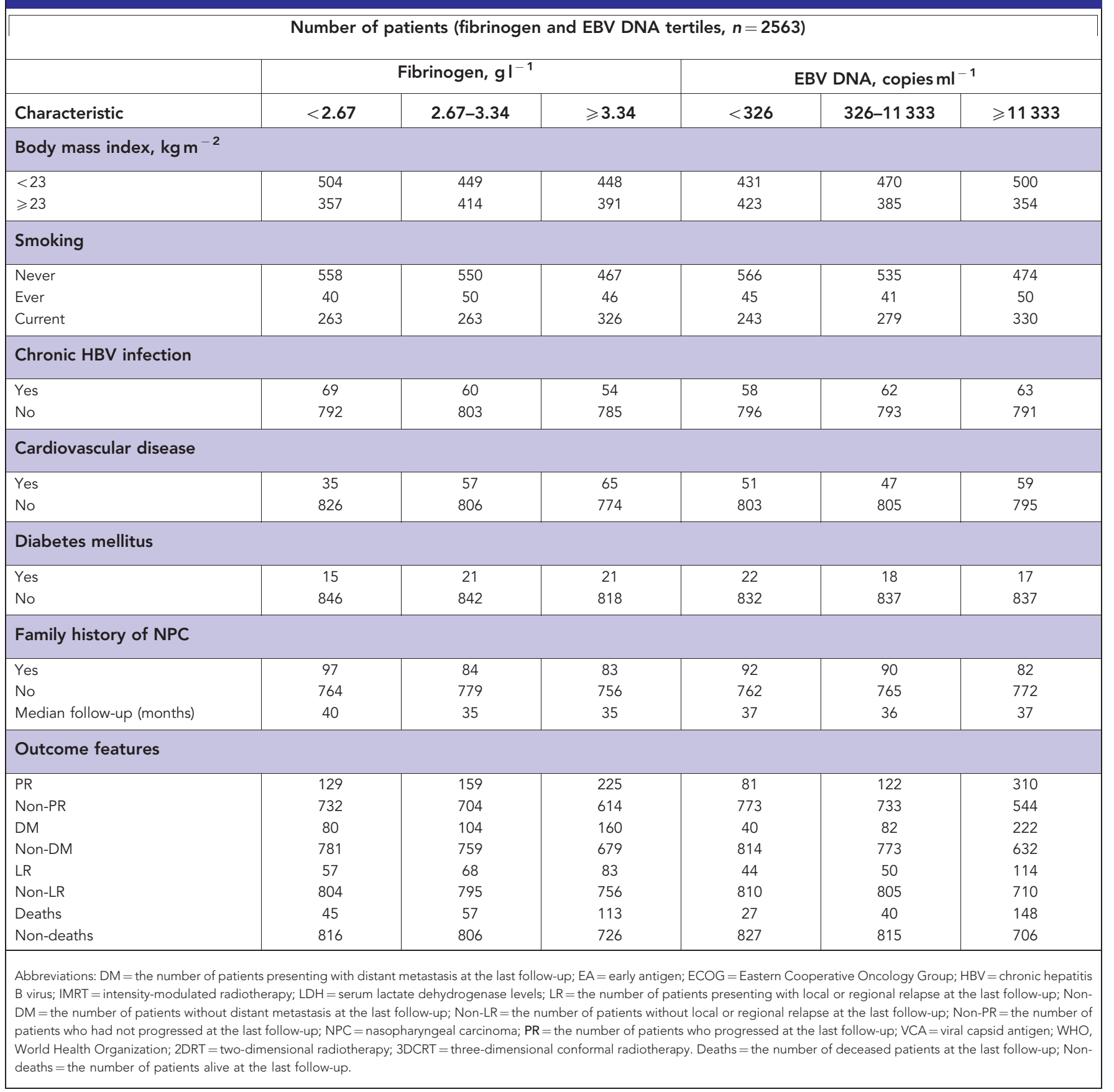

censoring at the date of the last follow-up. Patients still alive on 31 December 2013 (end of follow-up) were censored at the date of the last contact. After the treatment was complete, the patients were evaluated at 3-month intervals for the first 3 years and every 6 months thereafter.

Statistical analysis. Spearman rank correlation coefficients $\left(r_{\mathrm{s}}\right)$ were calculated for continuous variables, and fibrinogen and EBV DNA values were divided into tertiles. The Kaplan-Meier method was used to estimate the cumulative survival plot in relation to the variables divided according to their tertiles. The survival among groups was compared using the log-rank test. Hazard ratios (HRs) and 95\% confidence intervals (CIs) for EBV DNA and fibrinogen tertiles were estimated using Cox proportional hazards regression. We first adjusted for TNM stage and then further adjusted for age (years), sex, ECOG performance, pathological type, disease stage, treatment allocation, LDH, VCA-IgA, EA-IgA, smoking (never, former, current), cardiovascular disease (yes, no), diabetes mellitus (yes, no), familial history of NPC (yes, no) and body mass index. To assess potentially confounding variables or effect mediation by other biomarkers, the models assessing the association of fibrinogen with survival were further adjusted for EBV DNA and vice versa. We then evaluated the combined association of EBV DNA and fibrinogen with NPC patient survival by dividing participants into prespecified groups. We analysed the combined association according to high or low fibrinogen (above or below top tertile) and high or low EBV DNA ( $\geqslant 4000$ copies $\mathrm{ml}^{-1}$ or $<4000$ copies $\mathrm{ml}^{-1}$; Chan et al, 2002; Leung et al, 2006). In addition, we repeated this analysis of the combined association of EBV DNA and fibrinogen using tertiles of the above two biomarkers. Finally, statistical tests for 
interaction between fibrinogen and EBV DNA tertiles were performed using the TNM stage-adjusted Cox regression models. All reported probability values were two tailed, and $P<0.05$ was considered significant. Statistical analyses were performed with STATA version 8.2 and SPSS 17.0.

\section{RESULTS}

Patient characteristics and association with clinical variables. The characteristics of the 2563 NPC patients are listed in Table 1. The median follow-up time was 37 months (interquartile range (IQR): 28-46). The median fibrinogen level in patients with $(n=513)$ and without $(n=2050)$ relapse were 3.21 (IQR: 2.674.06) $\mathrm{gl}^{-1}$ and 2.95 (IQR: $\left.2.49-3.47\right) \mathrm{gl}^{-1}$, respectively $(P<0.001)$. The median EBV DNA levels were 22500 (IQR: 3280-130 000) copies $\mathrm{ml}^{-1}$ and 1940 (IQR: 0-14225) copies $\mathrm{ml}^{-1}$ in patients with and without relapse, respectively $(P<0.001)$. When examined as continuous variables, fibrinogen was positively correlated with EBV DNA $\left(r_{\mathrm{s}}=0.222, P<0.001\right)$. In addition, both fibrinogen and EBV DNA concentrations were significantly correlated with TNM staging ( $r_{\mathrm{s}}=0.231, P<0.001 ; r_{\mathrm{s}}=0.369, P<0.001 ;$ respectively). In total, 208 patients developed locoregional recurrences, 344 patients had distant metastases and 215 were deceased at the last follow-up.

HRs and 95\% CIs comparing fibrinogen and EBV DNA tertiles. Cumulative DFS, DMFS and OS probabilities for NPC patients indicate that EBV DNA tertiles are superior in survival prediction compared with fibrinogen tertiles (Figure 1), with $P<0.001$ from the log-rank significance tests across the tertile of either biomarker. As shown in Tables 2 and 3, both fibrinogen and EBV DNA are associated with DFS (TNM stage-adjusted HR: 1.81,
95\% CI: 1.45 to 2.26 for top fibrinogen tertiles; TNM stage-adjusted HR: $4.79,95 \%$ CI: 3.33 to 6.89 for top EBV DNA tertiles; both compared with the bottom tertiles). Linear associations were observed for fibrinogen tertiles 2 to 3 and EBV DNA tertiles 2 to 3. After adjusting for age and other risk factors (Tables 2 and 3), the upper tertiles of both biomarkers remained associated with DFS ( $P$ for trend $<0.001$ ).The HRs were 1.79 (95\% CI: 1.43 to 2.25 ) for the upper fibrinogen tertiles and 4.04 (95\% CI, 3.10 to 5.27) for the upper EBV DNA tertiles.

We further adjusted fibrinogen for EBV DNA in a Cox model. The HR comparing the top and bottom fibrinogen tertiles was slightly attenuated to 1.63 (95\% CI: 1.30 to 2.04); however, the trend across tertiles remained significant ( $P$ for trend $<0.001$; Table 2). Similarly, in a Cox model that adjusted EBV DNA for fibrinogen, the HR comparing the top and bottom EBV DNA tertiles was also mildly attenuated to 3.91 (95\% CI: 2.99 to 5.10), but the trend across tertiles remained significant ( $P$ for trend $<0.001$; Table 3 ). A similar finding was also observed for DMFS and OS regardless of HR adjusted for TNM stage or other risk factors.

Prognostic value of integrating plasma EBV DNA and fibrinogen levels. Combinatorial analyses of four prespecified groups of high and low EBV DNA or fibrinogen with DFS, DMFS and OS were performed (Figure 2). Reduced DFS, DMFS and OS were significantly associated with increased levels of both EBV DNA and fibrinogen. Increased DFS, DMFS and OS were significantly associated with low levels of both biomarkers $(P$ log-rank $<0.001)$. Of note, patients with high EBV DNA and low fibrinogen levels displayed increased event rates during follow-up compared with patients with low EBV DNA and high fibrinogen levels (Table 4). In subgroup analysis of advanced-stage disease (stages III and IV), the patients with high fibrinogen levels presented with worse DFS,
A

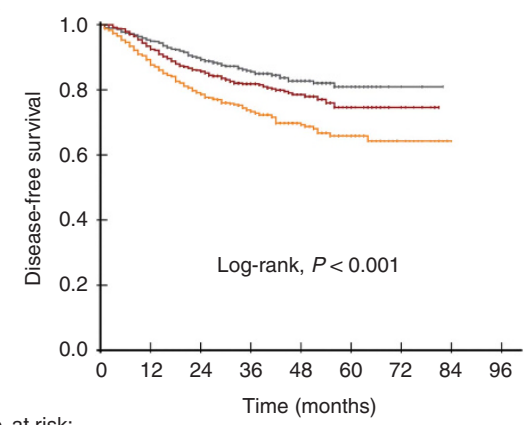

No. at risk:

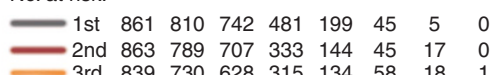

3rd 839 \begin{tabular}{llllllll}
230 & 607 & 333 & 144 & 45 & 17 & 0 \\
\hline
\end{tabular}

D

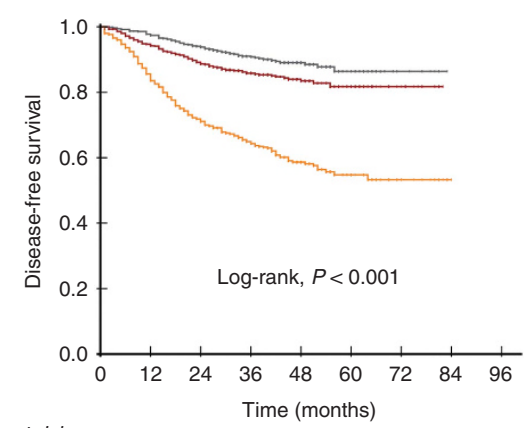

No. at risk:

—1st $854 \quad 826 \quad 772 \quad 415 \quad 181 \quad 49 \quad 8 \quad 0$ \begin{tabular}{lllllllll} 
2nd & 855 & 794 & 726 & 387 & 170 & 52 & 17 & 0 \\
\hline 3rd & 854 & 709 & 579 & 327 & 126 & 47 & 15 & 1
\end{tabular}
B

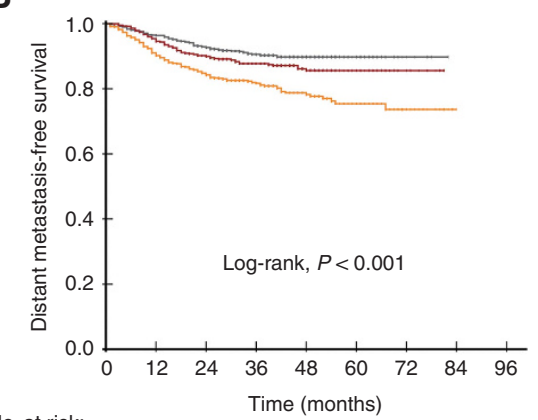

No. at risk:

1st $861 \quad 818 \quad 763 \quad 506 \quad 215 \quad 58 \quad 10 \quad 0$

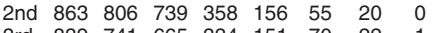
$\begin{array}{lllllllll}3 \text { rd } & 839 & 741 & 665 & 334 & 151 & 70 & 22 & 1\end{array}$

E

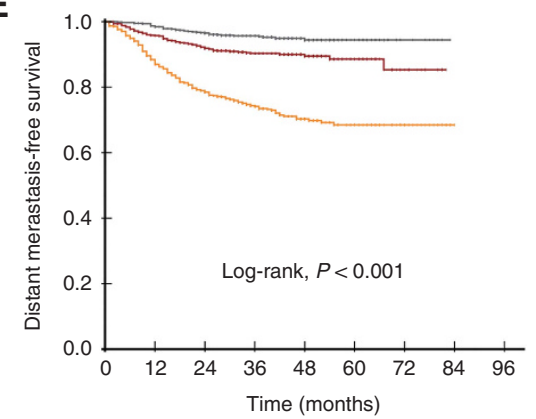

No. at risk:

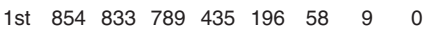
$\begin{array}{lllllllll}\text { 2nd } 855 & 804 & 748 & 404 & 178 & 57 & 17 & 0\end{array}$ $\begin{array}{lllllllll}\text { 3rd } & 854 & 728 & 630 & 369 & 148 & 68 & 26 & 1\end{array}$
C

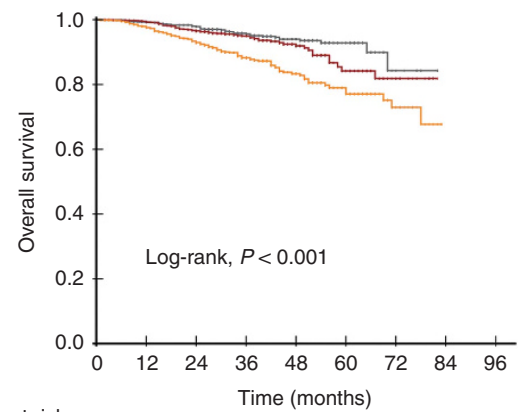

No. at risk:

$\begin{array}{lllllllll}1 \text { st } & 861 & 846 & 815 & 549 & 228 & 63 & 12 & 0\end{array}$

$\begin{array}{lllllllll}\text { 2nd } & 863 & 845 & 804 & 405 & 179 & 63 & 22 & 0\end{array}$

$\begin{array}{lllllllll}3 \text { rd } & 839 & 802 & 746 & 392 & 176 & 83 & 23 & 1\end{array}$

$\mathbf{F}$

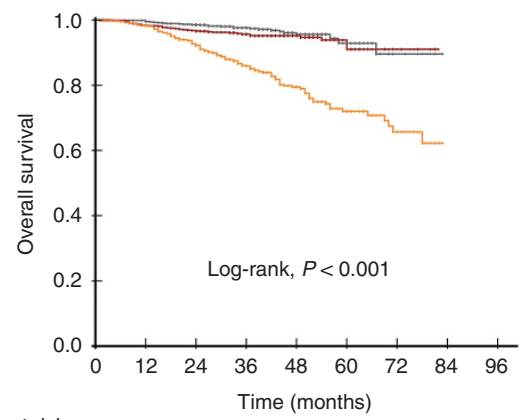

No. at risk:

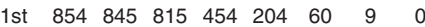

2nd $\begin{array}{lllllllll}855 & 828 & 798 & 444 & 194 & 66 & 18 & 0\end{array}$

$\begin{array}{llllllllll}3 \text { rd } & 854 & 820 & 752 & 448 & 185 & 83 & 30 & 1\end{array}$

Figure 1. Upper fibrinogen (A-C) and EBV DNA (D-F) tertiles are associated with DFS, DMFS and OS. $P<0.001$ for both variables as determined by log-rank significance tests. 
Table 2. DFS, DMFS and OS HRs according to fibrinogen tertiles

Fibrinogen tertile, $\mathrm{gl}^{-1}, \mathrm{n}=\mathbf{2 5 6 3}$

\begin{tabular}{|c|c|c|c|c|}
\hline & 1 & 2 & 3 & \\
\hline & $<2.67$ (Bottom) & $2.67-3.34$ & $\geqslant 3.34$ & $\boldsymbol{P}$-value(trend) \\
\hline \multicolumn{5}{|l|}{ DFS } \\
\hline $\begin{array}{l}\text { TNM stage-adjusted } \\
\text { Plus risk factors } \\
\text { Plus EBV DNA }\end{array}$ & $\begin{array}{l}1.00 \\
1.00 \\
1.00\end{array}$ & $\begin{array}{l}1.26(1.00-1.60) \\
1.30(1.03-1.65) \\
1.25(0.98-1.58)\end{array}$ & $\begin{array}{l}1.81(1.45-2.26) \\
1.79(1.43-2.25) \\
1.63(1.30-2.04)\end{array}$ & $\begin{array}{l}<0.001 \\
<0.001 \\
<0.001\end{array}$ \\
\hline \multicolumn{5}{|l|}{ DMFS } \\
\hline $\begin{array}{l}\text { TNM stage-adjusted }^{\mathbf{a}} \\
\text { Plus risk factors } \\
\text { Plus EBV DNA }\end{array}$ & $\begin{array}{l}1.00 \\
1.00 \\
1.00\end{array}$ & $\begin{array}{l}1.27(0.95-1.70) \\
1.31(0.97-1.76) \\
1.24(0.92-1.67)\end{array}$ & $\begin{array}{l}1.93(1.47-2.53) \\
1.89(1.43-2.50) \\
1.68(1.27-2.23)\end{array}$ & $\begin{array}{l}<0.001 \\
<0.001 \\
<0.001\end{array}$ \\
\hline \multicolumn{5}{|l|}{ os } \\
\hline $\begin{array}{l}\text { TNM stage-adjusted } \\
\text { Plus risk factors }{ }^{\mathbf{b}} \\
\text { Plus EBV DNA }\end{array}$ & $\begin{array}{l}1.00 \\
1.00 \\
1.00\end{array}$ & $\begin{array}{l}1.26(0.85-1.86) \\
1.21(0.81-1.80) \\
1.16(0.78-1.73)\end{array}$ & $\begin{array}{l}2.31(1.63-3.29) \\
2.08(1.45-2.98) \\
1.85(1.29-2.65)\end{array}$ & $\begin{array}{l}<0.001 \\
<0.001 \\
<0.001\end{array}$ \\
\hline
\end{tabular}

Abbreviations: DFS = disease-free survival; DMFS = distant metastasis-free survival; EBV DNA = Epstein-Barr Virus DNA; HR=hazard ratio; OS =overall survival; TNM stage = clinical stage for NPC based on the seventh American Joint Committee on Cancer (AJCC) TNM staging manual. The values represent hazard ratios ( $95 \%$ confidence interval).

a Obtained from Cox proportional hazard regression models adjusted for TNM stage (IV vs III vs II vs I).

' Obtained from Cox proportional hazard regression models adjusted for age ( $\geqslant 46$ years vs $<46$ years), sex (male vs female), WHO pathological type (undifferentiated non-keratinising vs differentiated non-keratinising vs keratinising squamous cell), ECOG performance status ( 2 vs $0-1$ ), chemoradiotherapy (yes vs no), radiation technique (intensity-modulated radiotherapy vs $3 \mathrm{D}$ CRT/2D-CRT), lactate dehydrogenase $\left(\geqslant 170 \mathrm{UI}^{-1} \mathrm{vs}^{2}<170 \mathrm{UI}^{-1}\right)$, viral capsid antigen $(\geqslant 1: 80 \mathrm{vs}<1: 80)$, early antigen $(\geqslant 1: 10 \mathrm{vs}<1: 10)$, body mass index $\left(\geqslant 23 \mathrm{~kg} \mathrm{~m}^{-2} \mathrm{vs}^{2}<23 \mathrm{~kg} \mathrm{~m}^{-2}\right)$, smoking status (yes vs no), concurrent cardiovascular disease (yes vs no), diabetes (yes vs no), chronic hepatitis disease (yes vs no) and family history of nasopharyngeal carcinoma (yes vs no). The lowest tertile of each biomarker served as the reference category for the hazard ratios. P-values were obtained from models, which were used to assess linear trends.

${ }^{c}$ Adjusted for all the above variables and EBV DNA.

Table 3. DFS, DMFS and OS HRs according to EBV DNA tertiles

EBV DNA tertile, copies $\mathrm{ml}^{-1}, \mathrm{n}=2563$

\begin{tabular}{|c|c|c|c|c|}
\hline & 1 & 2 & 3 & \\
\hline & $<326$ & $326-11333$ & $\geqslant 11333$ & $P($ trend) \\
\hline \multicolumn{5}{|l|}{ DFS } \\
\hline $\begin{array}{l}\text { TNM stage-adjusted } \\
\text { Plus risk factors }^{\mathbf{b}} \\
\text { Plus Fibrinogen }^{c}\end{array}$ & $\begin{array}{l}1.00 \\
1.00 \\
1.00\end{array}$ & $\begin{array}{l}1.49(1.12-1.98) \\
1.46(1.10-1.95) \\
1.45(1.09-1.94)\end{array}$ & $\begin{array}{l}4.24(3.27-5.49) \\
4.04(3.10-5.27) \\
3.91(2.99-5.10)\end{array}$ & $\begin{array}{l}<0.001 \\
<0.001 \\
<0.001\end{array}$ \\
\hline \multicolumn{5}{|l|}{ DMFS } \\
\hline $\begin{array}{l}\text { TNM stage-adjusted } \\
\text { Plus risk factors } \\
\text { Plus Fibrinogen }^{\mathbf{c}}\end{array}$ & $\begin{array}{l}1.00 \\
1.00 \\
1.00\end{array}$ & $\begin{array}{l}1.94(1.32-2.85) \\
1.95(1.32-2.87) \\
1.92(1.31-2.83)\end{array}$ & $\begin{array}{l}5.51(3.88-7.84) \\
5.34(3.72-7.66) \\
5.12(3.57-7.35)\end{array}$ & $\begin{array}{l}<0.001 \\
<0.001 \\
<0.001\end{array}$ \\
\hline \multicolumn{5}{|l|}{ os } \\
\hline $\begin{array}{l}\text { TNM stage-adjusted } \\
\text { Plus risk factors }{ }^{b} \\
\text { Plus Fibrinogen }{ }^{c}\end{array}$ & $\begin{array}{l}1.00 \\
1.00 \\
1.00\end{array}$ & $\begin{array}{l}1.29(0.78-2.11) \\
1.28(0.78-2.11) \\
1.25(0.76-2.06)\end{array}$ & $\begin{array}{l}4.38(2.86-6.70) \\
3.98(2.57-6.16) \\
3.76(2.42-5.82)\end{array}$ & $\begin{array}{l}<0.001 \\
<0.001 \\
<0.001\end{array}$ \\
\hline
\end{tabular}

Abbreviations: DFS = disease-free survival; DMFS = distant metastasis-free survival; EBV DNA = Epstein-Barr Virus DNA; HR, hazard ratio, OS =overall survival; TNM stage = clinical stage for NPC based on the seventh American Joint Committee on Cancer (AJCC) TNM staging manual. The values represent hazard ratios (95\% confidence interval).

a Obtained from Cox proportional hazard regression models adjusted for TNM stage (IV vs III vs II vs I).

b Obtained from Cox proportional hazard regression models adjusted for age ( $\geqslant 46$ years vs $<46$ years), sex (male vs female), WHO pathological type (undifferentiated non-keratinising vs differentiated non-keratinising vs keratinising squamous cell), ECOG performance status ( 2 vs $0-1$ ), chemoradiotherapy (yes vs no), radiation technique (intensity-modulated radiotherapy vs $3 \mathrm{D}$ -

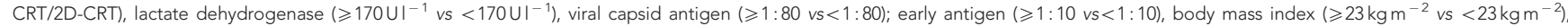
smoking status (yes vs no), concurrent cardiovascular disease (yes vs no), diabetes (yes vs no), chronic hepatitis disease (yes vs no) and family history of NPC (yes vs no). The lowest tertile of each biomarker served as the reference category for the hazard ratios. P-values were obtained from models used to assess linear trends.

${ }^{c}$ Adjusted for all the above variables and fibrinogen. 
A

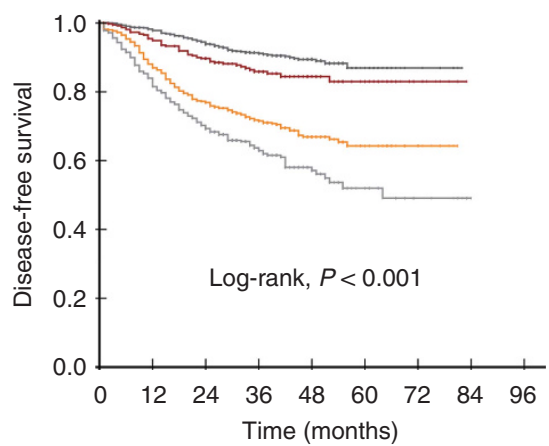

No. at risk:

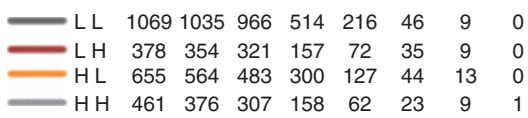

B

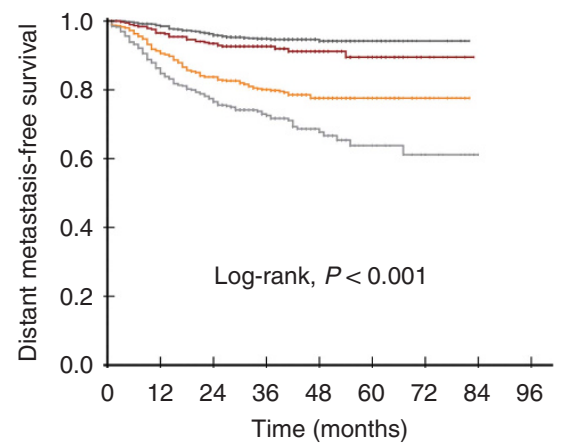

No. at risk:

L L $10691040983 \quad 553 \quad 230 \quad 55 \quad 10 \quad 0$

$\begin{array}{lllllllll}\text { L H } & 378 & 358 & 352 & 168 & 79 & 38 & 9 & 0\end{array}$

$\begin{array}{lllllllll}\mathrm{HL} & 655 & 584 & 519 & 331 & 141 & 58 & 20 & 0\end{array}$

$\begin{array}{lllllllll}\mathrm{HH} & 461 & 383 & 333 & 176 & 72 & 32 & 13 & 1\end{array}$
C

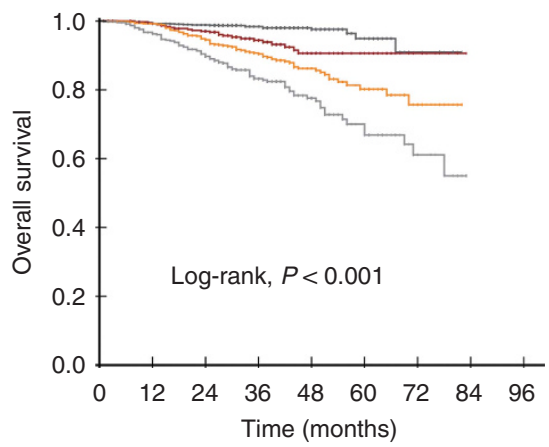

No. at risk:

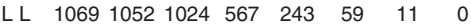

$\begin{array}{lllllllll}\text { LH } & 378 & 368 & 348 & 178 & 83 & 39 & 9 & 0\end{array}$

$\begin{array}{lllllllll}\mathrm{HL} & 655 & 639 & 595 & 387 & 164 & 67 & 23 & 0\end{array}$

$\begin{array}{lllllllll}\mathrm{HH} & 461 & 434 & 398 & 214 & 93 & 44 & 14 & 1\end{array}$

Figure 2. Kaplan-Meier curves of DFS, DMFS and OS according to the combination of pretreatment EBV DNA and fibrinogen levels in NPC patients. DFS (A), DMFS (B) and OS (C) values for 2563 patients. LL, $<4000$ copies ml ${ }^{-1}$ EBV DNA and $<3.34 \mathrm{gl}^{-1}$ fibrinogen; LH, $<4000$ copies $\mathrm{ml}^{-1}$ EBV DNA and $\geqslant 3.34 \mathrm{gl}^{-1}$ fibrinogen; $\mathrm{HL}, \geqslant 4000$ copies $\mathrm{ml}^{-1}$ EBV DNA and $<3.34 \mathrm{gl}^{-1}$ fibrinogen; HH, $\geqslant 4000$ copies ml $\mathrm{H}^{-1}$ EBV DNA and $\geqslant 3.34 \mathrm{gl}^{-1}$ fibrinogen.

DMFS and OS regardless of EBV DNA $\geqslant 4000$ or $<4000$ copies $\mathrm{ml}^{-1}$ subgroups. However, a significant difference for predicting distant metastasis in the low DNA group was not achieved. For patients with early stage disease (stages I and II), in the low DNA subgroup, high fibrinogen levels were associated with reduced DFS, DMFS and OS. Statistical significance was achieved for DMFS, but not for DFS and OS. In the high DNA subgroup, patients with high hs-CRP levels maintained reduced DFS, DMFS, and OS. However, statistical significance was only achieved for OS, but not for DFS and DMFS (Table 4).

We then divided the participants into nine categories according to EBV DNA and fibrinogen tertiles. Using patients with the lowest EBV DNA and fibrinogen levels (EBV DNA $<326$ copies $\mathrm{ml}^{-1}$ and fibrinogen $<2.67 \mathrm{gl}^{-1}$ ) as the reference group, the TNM stageadjusted HRs associated with DFS, DMFS and OS in patients with EBV DNA $\geqslant 11133$ copies $\mathrm{ml}^{-1}$ and fibrinogen $\geqslant 3.34 \mathrm{gl}^{-1}$ were 8.51(95\% CI, 5.34-13.56), 14.86 (7.13 to 30.95$)$ and 12.77 (5.08 to 32.12 ), respectively (Figure 3 ). When examined separately using the above cut-offs of high $v s$ low fibrinogen and EBV DNA levels, the TNM stage-adjusted HRs associated with DFS, DMFS and OS were 1.60 (95\% CI: 1.34 to 1.91 ), 1.69 (95\% CI: 1.36 to 2.10 ) and 2.05 (95\% CI: 1.56 to 2.69), respectively, for fibrinogen and 3.35 (95\% CI: 2.78 to 4.03 ), 3.64 (95\% CI: 2.89 to 4.59 ) and 3.77 (95\% CI: 2.80 to 5.08), respectively, for EBV DNA (data not shown). Patients with either upper values for EBV DNA but lower or intermediate values for fibrinogen or upper values for fibrinogen but lower or intermediate values for EBV DNA displayed poorer survival compared with patients with lower values for both biomarkers. Therefore, similar results were obtained when we employed tertile cut-offs to define increased EBV DNA levels compared with previously reported cut-offs. Multiplicative interactions between fibrinogen tertiles and EBV DNA categories with regard to relapse, distant metastasis and death were not observed; the $P$-values for these interactions were $0.554,0.760$ and 0.067 , respectively.

\section{DISCUSSION}

In this large-scale observational study of 2563 patients with nonmetastatic primary NPC, we found that increased EBV DNA and fibrinogen levels alone and in combination are associated with reduced DFS, DMFS and OS. Despite the positive correlation between EBV DNA and fibrinogen, increased levels of these biomarkers together were associated with reduced survival. The predictive value of EBV DNA was superior to that of fibrinogen, and the combinatorial effect was greater than the individual effects of either biomarker alone, without evidence of multiplicative interactions. Patients with $\geqslant 11133$ copies $\mathrm{ml}^{-1}$ of EBV DNA and $\geqslant 3.34 \mathrm{gl}^{-1}$ of fibrinogen display a greater than eightfold increased risk of disease progression compared with patients with $<326$ copies $\mathrm{ml}^{-1}$ of EBV DNA and $<2.67 \mathrm{gl}^{-1}$ of fibrinogen.

Previous studies (Lo et al, 1999; Chan et al, 2002; Lin et al, 2004; Leung et al, 2006; An et al, 2011) have examined the association between EBV DNA and NPC prognosis. In addition, the prognostic value of fibrinogen has also been demonstrated in other cancers (Takeuchi et al, 2007; Yamashita et al, 2009; Polterauer et al, 2009a; Polterauer et al, 2009b). However, the clinical value of fibrinogen alone or in combination with plasma EBV DNA has not been assessed in NPC. Interestingly, our findings demonstrate that EBV DNA and fibrinogen display an additive effect even upon adjustment for established risk factors. These results suggest a complementary role for these biomarkers in risk prediction that is not provided by standard risk factors or either biomarker alone.

Recent advancements in NPC patient classification and NPC molecular alterations, including microRNA signatures and the NPCSVM classifier (Wang et al, 2011a; Liu et al, 2012a), have been made. However, these developments required expensive and complicated procedures, and rapid clinical implementation was difficult to achieve. To date, routine prognostic risk assessment of NPC patients still relies on traditional clinico-pathological prognostic variables and EB virus-associated blood tests. Plasma fibrinogen levels are established, routinely measured blood-based parameters that are reproducibly detected without additional laborious efforts. Thus, fibrinogen is an attractive biomarker that is potentially useful for improving the prognostic stratification of NPC patients. Although EBV DNA combined with fibrinogen did not enhance prognostic prediction compared with EBV DNA alone in patients with early stage disease, the combination improved prognostic stratification in patients with advanced NPC (Table 4). These results suggest that these biomarkers may be selectively useful in advanced stage NPC. Although other established roles of plasma/serum EBV DNA were 
Table 4. Log-rank test on DFS, DMFS and OS for TNM stages split by EBV DNA and fibrinogen combination

\begin{tabular}{|c|c|c|c|c|c|c|c|c|c|c|}
\hline & & \multicolumn{2}{|c|}{ DFS } & & \multicolumn{2}{|c|}{ DMFS } & & \multicolumn{2}{|c|}{ OS } & \\
\hline Patients & $\begin{array}{l}\text { No. of } \\
\text { patients }\end{array}$ & $\begin{array}{l}\text { Events } \\
\text { (No.) }\end{array}$ & $\begin{array}{c}\text { DFS }(\%) \text { at } \\
3 \text { years }\end{array}$ & $P$-value & $\begin{array}{l}\text { Events } \\
\text { (No.) }\end{array}$ & $\begin{array}{c}\text { DMFS (\%) at } \\
3 \text { years }\end{array}$ & $P$-value & $\begin{array}{l}\text { Events } \\
\text { (No.) }\end{array}$ & $\begin{array}{l}\text { OS (\%) at } \\
3 \text { years }\end{array}$ & $P$-value \\
\hline \multicolumn{11}{|c|}{ All patients } \\
\hline \multicolumn{11}{|l|}{ Low DNA } \\
\hline Low Fbg & 1069 & 96 & $89(97.0-90.1)$ & & 54 & $94(92.0-96.0)$ & & 22 & $98(96.0-100.0)$ & \\
\hline High Fbg & 378 & 51 & 85 (81.1-88.9) & 0.007 & 30 & $91(87.1-94.9)$ & 0.031 & 23 & 91 (87.1-94.9) & $<0.001$ \\
\hline \multicolumn{11}{|l|}{ High DNA } \\
\hline Low Fbg & 655 & 192 & $67(63.1-70.9)$ & & 130 & 78 (74.1-81.9) & & 80 & $86(82.1-89.9)$ & \\
\hline High Fbg & 461 & 174 & $58(52.1-63.9)$ & 0.001 & 130 & $68(82.1-73.9)$ & $<0.001$ & 90 & 78 (74.1-81.9) & $<0.001$ \\
\hline \multicolumn{11}{|l|}{$I+I I$} \\
\hline \multicolumn{11}{|l|}{ Low DNA } \\
\hline Low Fbg & 277 & 15 & $94(92.0-96.0)$ & & 5 & $98(96.0-99.9)$ & & 4 & $99(97.0-100.0)$ & \\
\hline High Fbg & 44 & 5 & 85 (71.3-98.7) & 0.132 & 1 & $95(85.0-100)$ & 0.041 & 2 & $93(83-100.0)$ & 0.192 \\
\hline \multicolumn{11}{|l|}{ High DNA } \\
\hline Low Fbg & 44 & 16 & $59(41.4-76.6)$ & & 12 & $73(59.3-86.7)$ & & 2 & 98 (94.1-100.0) & \\
\hline High Fbg & 8 & 5 & $30(0.0-67.2)$ & 0.084 & 3 & $44(0.00-93.0)$ & 0.431 & 4 & $63(29.7-96.3)$ & 0.001 \\
\hline \multicolumn{11}{|l|}{ III + IV } \\
\hline \multicolumn{11}{|l|}{ Low DNA } \\
\hline Low Fbg & 792 & 81 & $87(85.0-89.0)$ & & 49 & $93(91.0-95.0)$ & & 18 & $97(95.0-99.0)$ & \\
\hline High Fbg & 334 & 34 & 85 (81.1-88.9) & 0.054 & 29 & $90(86.1-93.9)$ & 0.108 & 21 & 91 (87.1-94.9) & 0.001 \\
\hline \multicolumn{11}{|l|}{ High DNA } \\
\hline Low Fbg & 611 & 176 & $68(64.1-71.9)$ & & 118 & $78(74.1-81.9)$ & & 78 & 85 (81.1-88.9) & \\
\hline High Fbg & 453 & 169 & $58(52.1-63.9)$ & 0.001 & 127 & $69(63.1-74.9)$ & $<0.001$ & 86 & 78 (74.1-81.9) & 0.001 \\
\hline $\begin{array}{l}\text { Abbreviations: } \\
\text { NPC based on } \\
\text { EBV DNA; low } \\
\text { that occurred a }\end{array}$ & $\begin{array}{l}\text { sease-fre } \\
\text { nth Amer } \\
\text { hed as < }\end{array}$ & $\begin{array}{l}\text { al; DM } \\
\text { int Cor }\end{array}$ & $\begin{array}{l}\text { istant metastasis-f } \\
\text { e on Cancer (AJC } \\
\text {; high Fbg define }\end{array}$ & $\begin{array}{l}\text { Irvival, EE } \\
\text { IM stagin } \\
=3.34 \mathrm{gl}^{-}\end{array}$ & iual. Lc & $\begin{array}{l}\text { n-Barr Virus DNA; } \\
\text { NA defined as }<4 \\
\text { alues compared for }\end{array}$ & $\begin{array}{l}\text { hazard rati } \\
\text { copies } \mathrm{ml}^{-} \\
\text {rall log-ran }\end{array}$ & $\begin{array}{l}\text { S= overal } \\
\text { J DNA; hi } \\
\text { nd test. E }\end{array}$ & $\begin{array}{l}\text { vival; TNM stage }=c \\
\text { DNA defined as } \geqslant 40 \\
\text { ts }(\text { No. })=\text { the total nu }\end{array}$ & $\begin{array}{l}\text { ical stage fo } \\
\text { copies } \mathrm{ml}^{-} \\
\text {ber of event }\end{array}$ \\
\hline
\end{tabular}

confirmed in monitoring relapse (Leung et al, 2003b) and response to treatment (Chan et al, 2004), in patient follow-up (Wang et al, 2011b) (Hsu et al, 2013) and in population screening (Chan et al, 2013), the value of fibrinogen alone or combined with EBV DNA in these fields will require further exploration.

The mechanism by which these biomarkers combination improves the prognostic stratification of NPC patients is unclear. In addition to its role as an inflammatory biomarker, fibrinogen is the predominant coagulation factor in blood plasma and has an important role in platelet aggregation and fibrin formation (Hackam and Anand, 2003; Kerlin et al, 2004). Increased platelet counts promote distant metastases in NPC patients (Gao et al, 2013). Increased plasma fibrinogen levels may result from the production of tumour-associated cytokines or endothelial cells via the host $v s$ tumour response, the endogenous production of fibrinogen by tumour cells or tumour growth-induced hypercoagulation and hypoxia (Wenger et al, 1995; Palumbo et al, 2000; Wang et al, 2005; Sahni et al, 2008). Tumour growth increases hypoxia and induces tumour cell apoptosis. Previous studies demonstrated that EBV DNA molecules are released into the circulation by apoptosis and represent the tumour load (Mutirangura et al, 1998; Chan et al, 2003). This finding partially explains why EBV DNA levels correlate with fibrinogen levels. In addition, our findings potentially suggest that fibrinogen and EBV DNA may represent different signalling pathways or biological behaviours that contribute to NPC progression.
The major drawback of our study is the single measurement of both EBV DNA and fibrinogen. A single measurement potentially underestimates the magnitude of the association between the biomarkers and survival. The second limitation is that the data were obtained exclusively from one centre. Although our cancer centre treats a large number of NPC patients, these results need to be validated in other data sets. The third limitation is that the median follow-up time was 37 months. Patients remain closely followed, and we will report 5 -year follow-up results as available.

The study's strengths include reliable fibrinogen and EBV DNA measurements with high accuracy in a core laboratory and well-characterised risk factor profiles of patient that allowed for the control of potential confounding variables. In addition, the large sample size allowed both biomarkers to be examined individually and in combination for incident events and subgroup analysis.

In conclusion, our results suggest that plasma fibrinogen may serve as a new tool for assessing prognosis of NPC patients. In addition, the baseline assessment of both plasma EBV DNA and serum fibrinogen levels significantly improves DFS, DMFS and OS predictions as well as prognostic stratification of NPC patients according to TNM staging.

If the results from the forthcoming large collaborative studies confirm our results, this simple noninvasive approach may prove beneficial in prognostic stratification of NPC patients in clinical 
A

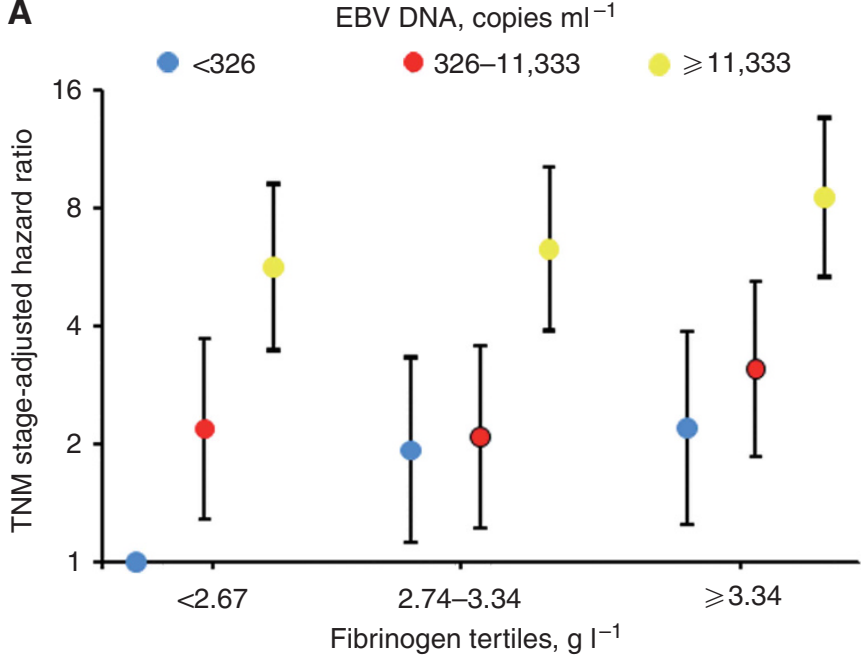

B
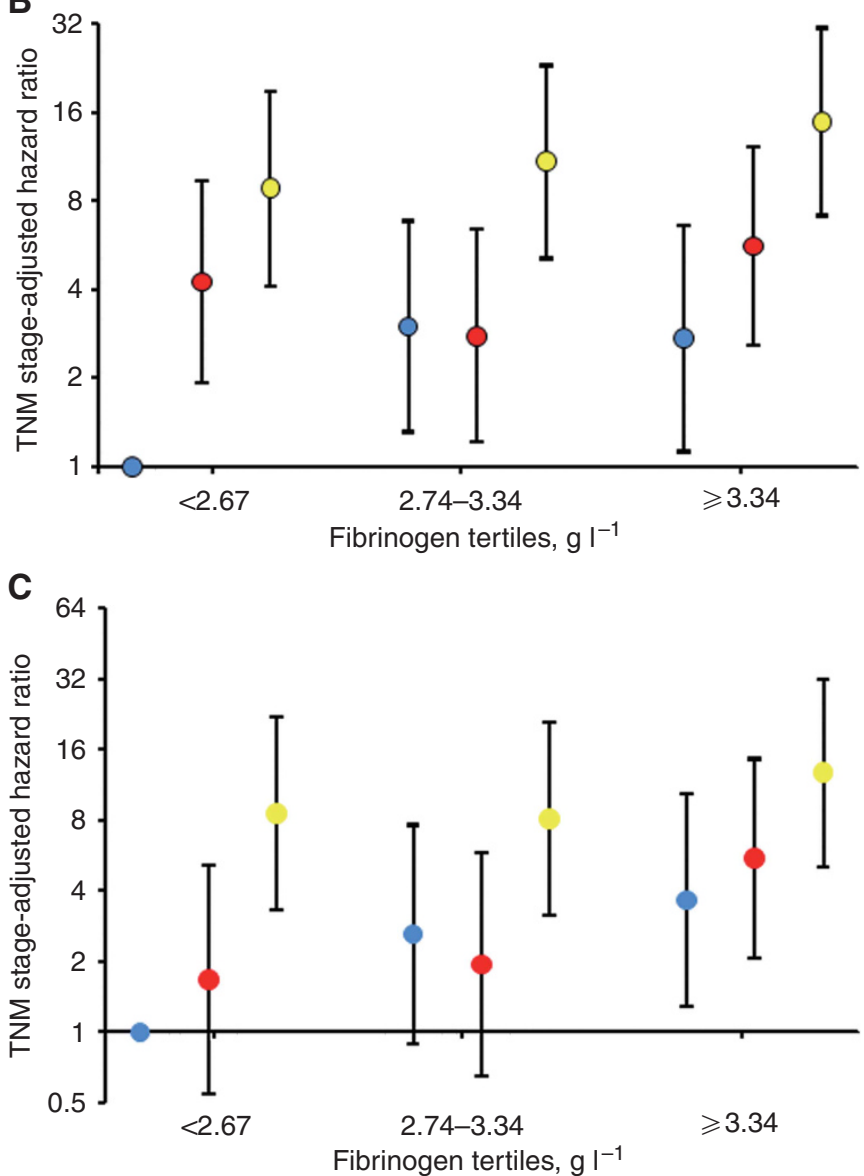

Figure 3. TNM stage-adjusted HRs predicting recurrence (A), distant metastasis (B) and death $(\mathbf{C})$ are presented for EBV DNA and fibrinogen on the $y$ axis. The fibrinogen tertile limits were $<2.67 \mathrm{gl}^{-1}$, 2.67 to $3.34 \mathrm{gl}^{-1}$ and $\geqslant 3.34 \mathrm{gl}^{-1}$. The EBV DNA tertile limits were

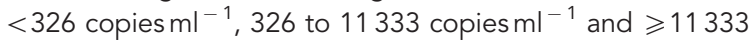
copies $\mathrm{ml}^{-1}$.

trials. The approach could be used to guide individual treatment, ultimately improving NPC outcome. However, randomised biomarker trials are required to determine whether this molecular staging strategy can improve NPC management compared with the conventional staging approach before implementation.

\section{ACKNOWLEDGEMENTS}

We gratefully recognise the patients who participated in this study. This study was partly supported by the Ministry of Science and Technology of China (No. 2011CB504300), the National Natural Science Foundation of China (81025014, 81230045, 91019015, 81071932,30600755 and 81072226), the 863 Project (No: 2012AA02A501), the National Key Basic Research Program of China (No: 2013CB910304), the Sci-Tech Project Foundation of Guangdong Province (No: 2011B080701034), the Sci-Tech Project Foundation of Guangzhou City (No: 2011J4300100), the Sun Yatsen University Clinical Research 5010 Program and the Fundamental Research Funds for the Central Universities.

\section{CONFLICT OF INTEREST}

The authors declare no conflict of interest.

\section{REFERENCES}

An X, Wang FH, Ding PR, Deng L, Jiang WQ, Zhang L, Shao JY, Li YH (2011) Plasma Epstein-Barr virus DNA level strongly predicts survival in metastatic/recurrent nasopharyngeal carcinoma treated with palliative chemotherapy. Cancer 117(16): 3750-3757.

Calvaruso V, Maimone S, Gatt A, Tuddenham E, Thursz M, Pinzani M, Burroughs AK (2008) Coagulation and fibrosis in chronic liver disease. Gut 57(12): 1722-1727.

Chan AT, Lo YM, Zee B, Chan LY, Ma BB, Leung SF, Mo F, Lai M, Ho S, Huang DP, Johnson PJ (2002) Plasma Epstein-Barr virus DNA and residual disease after radiotherapy for undifferentiated nasopharyngeal carcinoma. J Natl Cancer Inst 94(21): 1614-1619.

Chan AT, Ma BB, Lo YM, Leung SF, Kwan WH, Hui EP, Mok TS, Kam M, Chan LS, Chiu SK, Yu KH, Cheung KY, Lai K, Lai M, Mo F, Yeo W, King A, Johnson PJ, Teo PM, Zee B (2004) Phase II study of neoadjuvant carboplatin and paclitaxel followed by radiotherapy and concurrent cisplatin in patients with locoregionally advanced nasopharyngeal carcinoma: therapeutic monitoring with plasma Epstein-Barr virus DNA. J Clin Oncol 22(15): 3053-3060.

Chan KC, Hung EC, Woo JK, Chan PK, Leung SF, Lai FP, Cheng AS, Yeung SW, Chan YW, Tsui TK, Kwok JS, King AD, Chan AT, van Hasselt AC, Lo YM (2013) Early detection of nasopharyngeal carcinoma by plasma Epstein-Barr virus DNA analysis in a surveillance program. Cancer 119(10): 1838-1844.

Chan KC, Zhang J, Chan AT, Lei KI, Leung SF, Chan LY, Chow KC, Lo YM (2003) Molecular characterization of circulating EBV DNA in the plasma of nasopharyngeal carcinoma and lymphoma patients. Cancer Res 63(9): 2028-2032.

Chen L, Hu CS, Chen XZ, Hu GQ, Cheng ZB, Sun Y, Li WX, Chen YY, Xie FY, Liang SB, Chen Y, Xu TT, Li B, Long GX, Wang SY, Zheng BM, Guo Y, Mao YP, Tang LL, Chen YM, Liu MZ, Ma J (2012) Concurrent chemoradiotherapy plus adjuvant chemotherapy versus concurrent chemoradiotherapy alone in patients with locoregionally advanced nasopharyngeal carcinoma: a phase 3 multicentre randomised controlled trial. Lancet Oncol 13(2): 163-171.

Chen QY, Wen YF, Guo L, Liu H, Huang PY, Mo HY, Li NW, Xiang YQ, Luo DH, Qiu F, Sun R, Deng MQ, Chen MY, Hua YJ, Guo X, Cao KJ, Hong MH, Qian CN, Mai HQ (2011) Concurrent chemoradiotherapy vs radiotherapy alone in stage II nasopharyngeal carcinoma: phase III randomized trial. J Natl Cancer Inst 103(23): 1761-1770.

Clauss A (1957) [Rapid physiological coagulation method in determination of fibrinogen]. Acta Haematol 17(4): 237-246.

Cook NS, Ubben D (1990) Fibrinogen as a major risk factor in cardiovascular disease. Trends Pharmacol Sci 11(11): 444-451.

Gao J, Zhang HY, Xia YF (2013) Increased platelet count is an indicator of metastasis in patients with nasopharyngeal carcinoma. Tumour Biol 34(1): $39-45$.

Guo Q, Zhang B, Dong X, Xie Q, Guo E, Huang H, Wu Y (2009) Elevated levels of plasma fibrinogen in patients with pancreatic cancer: possible role of a distant metastasis predictor. Pancreas 38(3): e75-e79. 
Hackam DG, Anand SS (2003) Emerging risk factors for atherosclerotic vascular disease: a critical review of the evidence. JAMA 290(7): 932-940.

Hsu CL, Chan SC, Chang KP, Lin TL, Lin CY, Hsieh CH, Huang SF, Tsang NM, Lee LY, Ng SH, Wang HM (2013) Clinical scenario of EBV DNA followup in patients of treated localized nasopharyngeal carcinoma. Oral Oncol 49(6): 620-625.

Kerlin B, Cooley BC, Isermann BH, Hernandez I, Sood R, Zogg M, Hendrickson SB, Mosesson MW, Lord S, Weiler H (2004) Cause-effect relation between hyperfibrinogenemia and vascular disease. Blood 103(5): 1728-1734.

Leung SF, Chan AT, Zee B, Ma B, Chan LY, Johnson PJ, Lo YM (2003a) Pretherapy quantitative measurement of circulating Epstein-Barr virus DNA is predictive of posttherapy distant failure in patients with early-stage nasopharyngeal carcinoma of undifferentiated type. Cancer 98(2): 288-291.

Leung SF, Lo YM, Chan AT, To KF, To E, Chan LY, Zee B, Huang DP, Johnson PJ (2003b) Disparity of sensitivities in detection of radiationnaive and postirradiation recurrent nasopharyngeal carcinoma of the undifferentiated type by quantitative analysis of circulating Epstein-Barr virus DNA1,2. Clin Cancer Res 9(9): 3431-3434.

Leung SF, Zee B, Ma BB, Hui EP, Mo F, Lai M, Chan KC, Chan LY, Kwan WH, Lo YM, Chan AT (2006) Plasma Epstein-Barr viral deoxyribonucleic acid quantitation complements tumor-node-metastasis staging prognostication in nasopharyngeal carcinoma. J Clin Oncol 24(34): 5414-5418.

Lin JC, Wang WY, Chen KY, Wei YH, Liang WM, Jan JS, Jiang RS (2004) Quantification of plasma Epstein-Barr virus DNA in patients with advanced nasopharyngeal carcinoma. $N$ Engl J Med 350(24): 2461-2470.

Liu N, Chen NY, Cui RX, Li WF, Li Y, Wei RR, Zhang MY, Sun Y, Huang BJ, Chen M, He QM, Jiang N, Chen L, Cho WC, Yun JP, Zeng J, Liu LZ, Li L, Guo Y, Wang HY, Ma J (2012a) Prognostic value of a microRNA signature in nasopharyngeal carcinoma: a microRNA expression analysis. Lancet Oncol 13(6): 633-641.

Liu Y, Huang Q, Liu W, Liu Q, Jia W, Chang E, Chen F, Liu Z, Guo X, Mo H, Chen J, Rao D, Ye W, Cao S, Hong M (2012b) Establishment of VCA and EBNA1 IgA-based combination by enzyme-linked immunosorbent assay as preferred screening method for nasopharyngeal carcinoma: a two-stage design with a preliminary performance study and a mass screening in southern China. Int J Cancer 131(2): 406-416.

Lo YM, Chan LY, Lo KW, Leung SF, Zhang J, Chan AT, Lee JC, Hjelm NM, Johnson PJ, Huang DP (1999) Quantitative analysis of cell-free EpsteinBarr virus DNA in plasma of patients with nasopharyngeal carcinoma. Cancer Res 59(6): 1188-1191.

Lowe G, Woodward M, Hillis G, Rumley A, Li Q, Harrap S, Marre M, Hamet P, Patel A, Poulter N, Chalmers J (2013) Circulating inflammatory markers and the risk of vascular complications and mortality in people with type 2 diabetes mellitus and cardiovascular disease or risk factors: the advance study. Diabetes 63(3): 1115-1123.

Ludwig JA, Weinstein JN (2005) Biomarkers in cancer staging, prognosis and treatment selection. Nat Rev Cancer 5(11): 845-856.

Mora S, Rifai N, Buring JE, Ridker PM (2006) Additive value of immunoassay-measured fibrinogen and high-sensitivity C-reactive protein levels for predicting incident cardiovascular events. Circulation 114(5): 381-387.

Mosesson MW (2005) Fibrinogen and fibrin structure and functions. J Thromb Haemost 3(8): 1894-1904.

Mutirangura A, Pornthanakasem W, Theamboonlers A, Sriuranpong V, Lertsanguansinchi P, Yenrudi S, Voravud N, Supiyaphun P, Poovorawan Y (1998) Epstein-Barr viral DNA in serum of patients with nasopharyngeal carcinoma. Clin Cancer Res 4(3): 665-669.

Ng WT, Yuen KT, Au KH, Chan OS, Lee AW (2014) Staging of nasopharyngeal carcinoma - The past, the present and the future. Oral Oncol 50(6): 549-554.
Palumbo JS, Kombrinck KW, Drew AF, Grimes TS, Kiser JH, Degen JL, Bugge TH (2000) Fibrinogen is an important determinant of the metastatic potential of circulating tumor cells. Blood 96(10): 3302-3309.

Polterauer S, Grimm C, Seebacher V, Concin N, Marth C, Tomovski C, Husslein H, Leipold H, Hefler-Frischmuth K, Tempfer C, Reinthaller A, Hefler L (2009a) Plasma fibrinogen levels and prognosis in patients with ovarian cancer: a multicenter study. Oncologist 14(10): 979-985.

Polterauer S, Seebacher V, Hefler-Frischmuth K, Grimm C, Heinze G, Tempfer C, Reinthaller A, Hefler L (2009b) Fibrinogen plasma levels are an independent prognostic parameter in patients with cervical cancer. Am J Obstet Gynecol 200(6): 647 e1-647 e7.

Sahni A, Simpson-Haidaris PJ, Sahni SK, Vaday GG, Francis CW (2008) Fibrinogen synthesized by cancer cells augments the proliferative effect of fibroblast growth factor-2 (FGF-2). J Thromb Haemost 6(1): 176-183.

Sapkota B, Shrestha SK, Poudel S (2013) Association of activated partial thromboplastin time and fibrinogen level in patients with type II diabetes mellitus. BMC Res Notes 6: 485.

Shao JY, Li YH, Gao HY, Wu QL, Cui NJ, Zhang L, Cheng G, Hu LF, Ernberg I, Zeng YX (2004) Comparison of plasma Epstein-Barr virus (EBV) DNA levels and serum EBV immunoglobulin A/virus capsid antigen antibody titers in patients with nasopharyngeal carcinoma. Cancer 100(6): 1162-1170.

Sinning JM, Bickel C, Messow CM, Schnabel R, Lubos E, Rupprecht HJ, Espinola-Klein C, Lackner KJ, Tiret L, Munzel T, Blankenberg S (2006) Impact of C-reactive protein and fibrinogen on cardiovascular prognosis in patients with stable angina pectoris: the AtheroGene study. Eur Heart $J$ 27(24): 2962-2968.

Takeuchi H, Ikeuchi S, Kitagawa Y, Shimada A, Oishi T, Isobe Y, Kubochi K, Kitajima M, Matsumoto S (2007) Pretreatment plasma fibrinogen level correlates with tumor progression and metastasis in patients with squamous cell carcinoma of the esophagus. J Gastroenterol Hepatol 22(12): 2222-2227.

Wang HY, Sun BY, Zhu ZH, Chang ET, To KF, Hwang JS, Jiang H, Kam MK, Chen G, Cheah SL, Lee M, Liu ZW, Chen J, Zhang JX, Zhang HZ, He JH, Chen FL, Zhu XD, Huang MY, Liao DZ, Fu J, Shao Q, Cai MB, Du ZM, Yan LX, Hu CF, Ng HK, Wee JT, Qian CN, Liu Q, Ernberg I, Ye W, Adami HO, Chan AT, Zeng YX, Shao JY (2011a) Eight-signature classifier for prediction of nasopharyngeal [corrected] carcinoma survival. J Clin Oncol 29(34): 4516-4525.

Wang WY, Twu CW, Lin WY, Jiang RS, Liang KL, Chen KW, Wu CT, Shih YT, Lin JC (2011b) Plasma Epstein-Barr virus DNA screening followed by (1)(8)F-fluoro-2-deoxy-D-glucose positron emission tomography in detecting posttreatment failures of nasopharyngeal carcinoma. Cancer 117(19): 4452-4459.

Wang X, Wang E, Kavanagh JJ, Freedman RS (2005) Ovarian cancer, the coagulation pathway, and inflammation. J Transl Med 3: 25.

Wee JT, Ha TC, Loong SL, Qian CN (2010) Is nasopharyngeal cancer really a 'Cantonese cancer'? Chin J Cancer 29(5): 517-526.

Wei WI, Sham JS (2005) Nasopharyngeal carcinoma. Lancet 365(9476): 2041-2054.

Wenger RH, Rolfs A, Marti HH, Bauer C, Gassmann M (1995) Hypoxia, a novel inducer of acute phase gene expression in a human hepatoma cell line. J Biol Chem 270(46): 27865-27870.

Yamashita H, Kitayama J, Taguri M, Nagawa H (2009) Effect of preoperative hyperfibrinogenemia on recurrence of colorectal cancer without a systemic inflammatory response. World J Surg 33(6): 1298-1305.

This work is published under the standard license to publish agreement. After 12 months the work will become freely available and the license terms will switch to a Creative Commons AttributionNonCommercial-Share Alike 3.0 Unported License. 